\title{
Sugarcane Cutting Machine
}

\author{
Vahid Jamadar ${ }^{1}$, Arbaz Sawar ${ }^{2}$, Hemant Pol $^{3}$, Niraj Deshpande ${ }^{4}$, Sandip Sawant ${ }^{5}$, Vishnu Patil ${ }^{6}$ \\ Assistant Prof., AGTI's Dr. Daulatrao Aher College of Engineering, Karad, India ${ }^{1}$ \\ BE, Mechanical Department, AGTI's Dr. Daulatrao Aher College of Engineering, Karad, India 2, 3, 4, 5, 6
}

\begin{abstract}
This research paper helps to design and fabricate small scale sugarcane cutting machine for sugarcane harvesting to reduce farmer's effort and to increase production of agricultural goods. Compared to manual harvesting this machine has a capacity to cut canes in faster rate. It is economical. This paper helps in laying design foundation for any aspiring user to fabricate a machine for application in their farms. It helps improve economic growth of the nation.
\end{abstract}

Keywords: sugarcane cutting machine, design and fabrication of mini sugarcane cutting machine, force analysis of sugarcane, reduce harvesting time.

\section{INTRODUCTION}

In agricultural harvesting we require maximum man power, ample money and also it is more time consuming process. In cutting process we face various problems and these are not easily solved. The design of this machine is very simple also easy to implement. In this manner we are designing the Sugarcane Cutting Machine to reduce effort and time. In sugar cane farms we are using this machine for cutting purpose. This is user friendly cutting machine, anyone can handle this machine in any working condition. Skilled persons aren't required for operating this machine.

\section{LITERATURE REVIEW}

Caryn Elizabeth Benjamin [1] The project here involved the design and testing of a sugar cane yield monitoring system during the 1999 and 2000 harvest year. The system was mounted on a CAMECO CH 25001997 sugar cane combine harvester. The sugar cane yield monitoring system consisted of a scale, a data acquisition system, and a differential global positioning system (DGPS). The scale consisted of a weighing machine supported by load cells. The load cells were protected in a enclosed box, which mounted to the frame of this machine. The weighing equipment, which was mounted at the base of the elevator, directly recorded instantaneous figures of the sugar cane yield. A dump wagon equipped with a weighing equipment consisting of load cell was used for each test as the standard.

Experiments were conducted with different conditions of cane maturity, variety, row/section length, and flow rate. For each test, the scale readings were total and compared to the actual yield, which was measured by the weigh wagon. The yield sensor predicted the sugar cane yield with a slope of 0.900 and a R-squared of 0.966 . The scale's average percent error was 11.05 percent. It resulted into showing that the different cane varieties had an effect on the scale readings, but the maturity of the cane, section length, and the flow rate did not have a significant effect on the scale readings.
Dr. Sharad S. Chaudhari [2] There project aimed at designing and fabricating small scale sugarcane harvester for sugarcane harvesting to reduce farmer's effort and to increase production of agricultural products. Machine consists of petrol engine and different mechanisms. When compare to manual harvesting by using this machine has a capacity to cut canes in faster rate and it is economical. The machine is helpful for both whom having small or big farms.

Joby Bastian [3] The mechanical properties of the plant material significantly influence the performance of the different unit operation in combine harvester. Hence, studies of these properties were done prior to the design of sugarcane harvesting system. The mechanical properties of sugarcane stalk viz., bending resistance, cutting resistance, penetration resistance and crushing resistance were studied in the laboratory. It is found that the Young's modulus of the sugarcane stalks as $86 \mathrm{MPa}$, The specific cutting resistance varies between 1764.56 and $957.48 \mathrm{kN} / \mathrm{m}^{\wedge} 2$, penetration resistance ranging from $29.74 \mathrm{kN} / \mathrm{m}^{\wedge} 2$ to $56.33 \mathrm{kN} / \mathrm{m}^{\wedge} 2$ and the crushing force varied from $0.75 \mathrm{kN}$ to $1.53 \mathrm{kN}$. this study helped us very much while deciding the forces required to cut the cane in one knocking stroke.

R. R. Price [4] A fiber optic yield monitoring system was developed for a sugarcane chopper harvester that utilized a duty cycle type approach with three fiber optic sensors mounted in the elevator floor to estimate sugarcane yield. Field testing of the monitor demonstrated that there was a zero intercept linear relationship between the optical sensor response and the actual sugarcane yields with an R2 value of 0.98 . The average observed prediction error on 0.5 to $1.6 \mathrm{Mg}$ estimates was $7.5 \%$; though, the magnitude of the error decreased as the harvested area (tonnage) increased, with an estimated error of $0.03 \%$ for $57.8 \mathrm{Mg}$ loads. Factor testing indicated that the duty cycle reading was not affected by different conditions like sugarcane variety, harvester speed, harvested distance, or direction of cut. Field testing across several locations in the U.S. total was more than $557 \mathrm{~h}$ of operation and indicated that the 
IARJSET

Vol. 3, Special Issue 4, September 2016

system was robust, maintenance free, and self cleaning, fs $=18.75 \mathrm{~N} / \mathrm{mm}^{\wedge} 2$

but some obstruction of the fiber optic sensors did occur in So, To find diameter of cutter shaft is as follows,

wet, muddy soils. These obstructions were minimized by $\mathrm{T}=(\pi / 16) * \mathrm{fs} *\left(\mathrm{~d}^{\wedge} 3\right)$

relocating the fiber optics closer to the bottom of the $71.21=(\pi / 16)^{*} 18.75^{*}\left(\mathrm{~d}^{\wedge} 3\right)$

elevator and leaving holes on each side of the sensors to $d=25 \mathrm{~mm}$

enhance cleaning and scouring. This monitoring system Diameter of cutter shaft is $25 \mathrm{~mm}$.

compares well with all previously tested methods and is Checking torsion failure in cutter shaft

very durable and easy to install.

$\mathrm{T}=(\pi / 16) * \mathrm{fs}^{*}\left(\mathrm{~d}^{\wedge} 3\right)$

Suleiman Samaila [5] Sugarcane harvesting is a labour $71.21 * 10^{\wedge} 3=(\pi / 16) * f s^{*}\left(25^{\wedge} 3\right)$

concentrated operation and its mechanization is a modern fs $=23.24 \mathrm{~N} / \mathrm{mm}^{\wedge} 2$

development in Nigeria. The difficulties in providing the Design is not safe because shear force is maximum

needed spare parts for the imported harvesting machines So, we are increasing the diameter of cutter shaft

and labour shortages during harvesting periods hamper the Consider diameter of cutter shaft $=30 \mathrm{~mm}$

country's drive towards self-reliance in sugar production. Again checking torsion failure in cutter shaft

To develop an effective and efficient machine for $\mathrm{T}=(\pi / 16) * \mathrm{fs}^{*}\left(\mathrm{~d}^{\wedge} 3\right)$

harvesting of sugarcane, a preliminary data on the energy $71.21 * 10^{\wedge} 3=(\pi / 16)^{*} \mathrm{fs} *\left(30^{\wedge} 3\right)$

requirement for the cutting and topping of sugarcane must fs $=13.42 \mathrm{~N} / \mathrm{mm}^{\wedge} 2$

be available for that a simple apparatus was developed to So, Design is safe

calculate the energy requirement for cutting and topping of Diameter of cutter shaft is $30 \mathrm{~mm}$.

sugarcane. The apparatus consists of: crank, sprocket, Diameter of pulley:

chain, freewheel, flange, front hub, spindle, frame and the $T=(\pi / 16)^{*} f s^{*}\left(d^{\wedge} 3\right)^{*}\left(1-K^{\wedge} 4\right)$

base support. The result was 15.71 Joules and 23.83 Joules $\left(71.21^{*} 10^{\wedge} 3 * 16\right) /\left(\pi^{*} 18.75^{*} 30^{\wedge} 3\right)=\left(1-K^{\wedge} 4\right)$

were needed for cutting the top and base of the sugarcane, $K=0.7298$

respectively.

Prof. N.M. Pachkhand [6] In today's world there is a need for faster rate of production of agricultural products. Agriculture is the backbone of India. In India almost all farmers facing problems of labour shortage. Day by day labour wages are increasing and in the same way demand of agriculture products are also increasing and today's world need faster rate of production of agriculture products. This project aims to design and fabricate small scale sugarcane harvesting machine to reduce farmer's effort and to increase production of agricultural products. This machine consists of petrol engine with different mechanisms. When compared to manual harvesting this machine has a capacity to cut canes in faster rate and it is economical.

\section{DESIGN OF CUTTER}

Design of Shaft:

For designing cutter shaft we are consider 1HP electric motor A.C supply $720 \mathrm{rpm}$.

So, calculating design of shaft as follows,

$\mathrm{P}=2 * 3.14 * \mathrm{~N} * \mathrm{~T} / 60$

Where,

$\mathrm{P}=$ Power of motor in $\mathrm{KW}$

$\mathrm{T}=$ Torque in $\mathrm{N}-\mathrm{m}$

$\mathrm{K}=(\mathrm{Di} / \mathrm{Do})$

Where;

$\mathrm{Di}=$ Internal diameter of pulley in $\mathrm{mm}$

Do $=$ External diameter of pulley in $\mathrm{mm}$

$(\mathrm{Di} / \mathrm{Do})=0.7297$

$(\mathrm{Di} / \mathrm{Do})=(\mathrm{No} / \mathrm{Ni})$

$(30 / \mathrm{Do})=(100 / 720)$

$\mathrm{Do}=180 \mathrm{~mm}$

So, Dimension of pulley as follows,

Internal diameter of pulley $=30 \mathrm{~mm}$

Outer diameter of pulley $=180 \mathrm{~mm}$

Assumptions;

1) As providing chain drive, not much tension produces on shaft so no design consideration in bending stresses on shaft is needed.

2) The optimum speed reduction from $720 \mathrm{rpm}$ to 100 rpm is obtained by using sprocket of $30 \mathrm{~mm}$ diameter of motor pulley and $180 \mathrm{~mm}$ of cutter bar sprocket.

3) It is recommend using axial thrust bearing for carrying load of $80 \mathrm{~N}$ thrust load of cutter shaft.

Design of Cutter:

$\mathrm{T}=\mathrm{F} * \mathrm{R}$

$\mathrm{T}=11.58 \mathrm{~N}-\mathrm{m}$

Cutting force $=106.5 \mathrm{~N}$

Hence cutter radius $=108.73 \mathrm{~mm}$

It is recommend to use case hardened cutting steel for cutter. Use standard cane cutter blades available in the agriculture equipment shops locally.

$\mathrm{T}=71.21 \mathrm{~N}-\mathrm{m}$

So, Considering material for bar is mild steel, Therefore,

$\mathrm{Syt}=150 \mathrm{~N} / \mathrm{mm}^{\wedge} 2$ and F.O.S $=4$

fs $=0.5 *$ Syt/F.O.S

Where;

$\mathrm{fs}=$ Shear stress in $\mathrm{N} / \mathrm{mm}^{\wedge} 2$

$\mathrm{fs}=0.5 * 150 / 4$

\section{CONCEPTUAL CAD MODEL}

Automation in agriculture is the need for huge agricultural based economies like India. Today graduating engineers must concentrate to improve this field. 
IARJSET

Vol. 3, Special Issue 4, September 2016

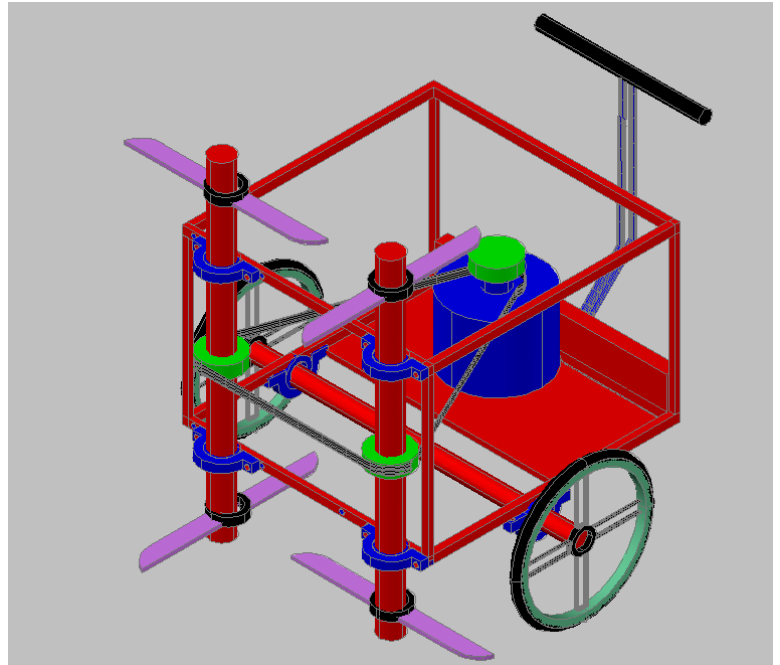

Fig. 1. Sugarcane Cutting Machine Proposed Model

Automation has very huge scope in both cultivation and harvesting of such agricultural application. Sugarcane is tall grass with thick stalk and is cut manually by steel blades and transported to nearly sugar factories. The present sugarcane harvesters are big in size and of huge cutting capacity. Due to their size it is next to impossible to use these automatic harvesters in the small farm. It is also not very economically viable to the poor segment of the country like here in India. In this paper an attempt is made to design and manufacture a small semiautomatic sugarcane cutter by fabricating it locally and hence prove using this design people may fabricate their very own semi automatic cutters at their locale. The design is very simple and can be fabricated with local fabricators. Both AC and DC power can be used, depending upon the availability of power or even an I.C engine can be used. The machine is simple and can be operated by four operators, two for driving and two for shredding.

\section{CONCLUSION}

This design permits to have a capacity to cut approximately half acres of sugarcane cultivated land/hr. Comparing with manual harvesting half of harvesting time and need of labours are reduced. The cost of harvesting is reduced by many folds when compare to manual harvesting.

Table. 1. List of the component with cost:

\begin{tabular}{|c|c|c|c|}
\hline Name & Dimension & Quantity & Cost (Rs.) \\
\hline Rod & $\begin{array}{c}\text { Diameter } \\
50 \mathrm{~mm}\end{array}$ & 3 & 1092 \\
\hline $\begin{array}{c}\text { Steel } \\
\text { angle }\end{array}$ & $\begin{array}{c}1500 \mathrm{~mm} * \\
50 \mathrm{~mm}\end{array}$ & 8 & 1248 \\
\hline $\begin{array}{c}\text { Square } \\
\text { angle }\end{array}$ & $\begin{array}{c}1000 \mathrm{~mm} * \\
50 \mathrm{~mm}\end{array}$ & 4 & 832 \\
\hline Pulley & $\begin{array}{c}\text { Inner dia. } \\
50 \mathrm{~mm}\end{array}$ & 4 & 1000 \\
\hline
\end{tabular}

\begin{tabular}{|c|c|c|c|}
\hline & $\begin{array}{c}\text { Outer dia. } \\
100 \mathrm{~mm}\end{array}$ & & \\
\hline $\begin{array}{l}\text { Frame } \\
\text { plate }\end{array}$ & $\begin{array}{c}1500 \mathrm{~mm} * \\
500 \mathrm{~mm}\end{array}$ & 1 & 300 \\
\hline Blade & $500 \mathrm{~mm}$ & 4 & 400 \\
\hline Motor & $\begin{array}{c}\text { HP - } 1 \\
\text { Speed } 1440 \\
\text { rpm } \\
\text { Supply AC } \\
240 \text { volt }\end{array}$ & 1 & 3500 \\
\hline Handle & $\begin{array}{c}1000 \mathrm{~mm} * \\
200 \mathrm{~mm}\end{array}$ & 1 & 364 \\
\hline Wheel & $\begin{array}{l}\text { Diameter } \\
1000 \mathrm{~mm}\end{array}$ & 2 & 1200 \\
\hline $\begin{array}{c}\text { Nut and } \\
\text { bolt }\end{array}$ & M12 & 8 & 384 \\
\hline
\end{tabular}

Total cost INR $=10320 /-$, This data is given so as to compel every farmer to use such basic automation. When comparing with the large scale, though the harvesting time and energy consumption is less in large scale, but the cost of machine is very high around 20 million rupees and the cost of the small scale machine is Rs. 10500 . So it will be helpful to our farmer. By comparing with manual harvesting, Rs. 10,000 for an acre can be saved by small scale harvesting machine. So very less time is needed to return one's investment.

\section{ACKNOWLEDGMENT}

The authors would like to express sincere gratitude to Department of Mechanical Engineering, AGTI's Dr. Daulatrao Aher College of Engineering, Karad, Satara, India for their help and support.

\section{REFERENCES}

[1] Caryn Elizabeth Benjamin, "Sugar Cane Yield Monitoring System", B.S. B.E., Louisiana State University, Graduate Faculty of the Louisiana State University, 2002.

[2] Mr. Rohit J.Masute, Dr. Sharad S.Chaudhari and Prof .S. S. Khedkar, "Design And Fabrication Of Small Scale Sugarcane Harvester", IJRDO-Journal Of Mechanical And Civil Engineering, 2015.

[3] Joby Bastian and B. Shridar, "Investigation on Mechanical Properties of Sugarcane Stalks for the Development of a Whole Cane Combine Harvester", Indian Journal Of Applied Research, 2014

[4] R. R. Price, R. M. Johnson, R. P. Viator, J. Larsen and A. Peters, "Fiber Optic Yield Monitor For A Sugarcane Harvester", American Society of Agricultural and Biological Engineer, 2011.

[5] Suleiman Samaila, Hamid Mohammed Al-Sharief and Salihu Ahmed Abdulkadir, "Development of a Tool to Determine the Energy Required to Cut and Top Sugarcane", Department of Agricultural Engineering, Adamawa State Polytechnic Yola, Adamawa State, Nigeria, 2012.

[6] Prof. N.M. Pachkhande, Dhiraj V. Rade and Vikas G. Nagapure, "Small Scale Sugarcane Cutter Machine", International Journal For Engineering Applications And Technology, 2015.

[7] V. B. Bhandari, "Design of Machine Elements", Tata Mcgraw Hill Book Company, 2010.

[8] R. S. Khurmi and J.K Gupta, "Machine Design”, Tata Mcgraw Hill Book Company, 2005. 